AperTO - Archivio Istituzionale Open Access dell'Università di Torino

\title{
Back and forth from basic science to clinical translation
}

\section{This is the author's manuscript}

Original Citation:

\section{Availability:}

This version is available http://hdl.handle.net/2318/1798012

since 2021-08-26T12:43:10Z

Published version:

DOI:10.23736/S0375-9393.20.14555-3

Terms of use:

Open Access

Anyone can freely access the full text of works made available as "Open Access". Works made available under a Creative Commons license can be used according to the terms and conditions of said license. Use of all other works requires consent of the right holder (author or publisher) if not exempted from copyright protection by the applicable law. 


\section{Back and Forth from Basic Science to Clinical Translation}

Dear Editor, I enjoyed reading the interesting mini-review "Perioperative cardioprotection: back to bedside" by Lionetti and Barile ${ }^{1}$. The authors have done an excellent job in summarizing the most salient aspects of this relevant and timely topic: how to prevent perioperative myocardial injury (MI) in cardiac and noncardiac surgery. The incidence of perioperative MI seems to be quite higher in cardiac surgery. Therefore, the majority of experts focus on this issue. However, given the huge number of surgical interventions also noncardiac surgery deserves to be considered. The authors should be commended for the effort they have made in considering these critical aspects in a balanced and precise way. Here I would like to underline the point of view of the basic researcher, who is trying to understand how the benefits observed in the laboratory can be translated into the clinical scenario. As pointed out by Lionetti and Barile, the researchers focused on studying cardiomyocytes mainly, however we understood that it is necessary to consider a plethora of cells (cardiac and non-cardiac) ${ }^{2}$. Furthermore, not only cell death from necrosis matters: under stress and hypoxygenation cardiac cells can die with different mechanisms ${ }^{3}$. Moreover, a neglected aspect is coronary microvascular dysfunction (CMD), which can also be involved in non-cardiac surgery in subjects with comorbidities and apparent normal coronary perfusion under basal conditions. Even in the absence of appreciable atherosclerosis, a fairly severe CMD can produce alterations in the myocardial oxygen balance, particularly during stress ${ }^{4}$, such as during surgery. Last but not least, there is an urgent need to standardize cardioprotective procedures in laboratories and hospital wards ${ }^{5}$. Basic research on micro-vesicles (released by circulating cells and by all types of cells present in the heart tissue), epigenomic and genomic aspects, as underlined by Lionetti and Barile, will be the tools that will allow a huge step forward in precision medicine and in perioperative care. Lionetti and Barile are among the pioneers who stressed the importance of these aspects and the paracrine effects of the factors released by cells.

In conclusion, the Lionetti and Barile review suggests that we must identify new signaling pathways and therapeutic targets for cardioprotection, aimed at multiple signaling pathways and final effectors both inside and outside the cardiomyocyte, for an efficient multitarget therapy. We must consider the co-medications and co-morbidities that influence cardioprotection and the mechanisms of their interference in appropriate animal models. Only if basic and clinical researchers find new strategies and more effective approaches to cardioprotection and improves the rigor and reproducibility of experimental approaches, we can improve clinical translation and patient benefits. We need to go back and forth from the lab to the bedside to better understand the mechanisms of cardioprotection in order to counter stagnation in the clinical management of patients.

1. Lionetti V, Barile L. Perioperative cardioprotection: back to bedside. Minerva Anestesiol. 2019 Dec 4. doi: 10.23736/S0375-9393.19.13848-5. 
2. Davidson SM, Andreadou I, Barile L, Birnbaum Y, Cabrera-Fuentes HA, Cohen MV, Downey JM, Girao H, Pagliaro P, Penna C, Pernow J, Preissner KT, Ferdinandy P. Circulating blood cells and extracellular vesicles in acute cardioprotection. Cardiovasc Res. 2019 Jun 1;115(7):1156-1166. doi: $10.1093 / \mathrm{cvr} / \mathrm{cvy} 314$.

3. Davidson SM, Adameová A, Barile L, Cabrera-Fuentes HA, Lazou A, Pagliaro P, Stensløkken K-O, Garcia-Dorado D. Mitochondrial and mitochondrial-independent pathways of myocardial cell death during ischaemia and reperfusion injury. J Cell Mol Med 2020, In press.

4. van de Wouw J, Sorop O, van Drie RWA, van Duin RWB, Nguyen ITN, Joles JA, Verhaar MC, Merkus $D$, Duncker DJ. Perturbations in myocardial perfusion and oxygen balance in swine with multiple risk factors: a novel model of ischemia and no obstructive coronary artery disease. Basic Res Cardiol. 2020 Feb 25;115(2):21. doi:10.1007/s00395-020-0778-2.

5. Bøtker HE, Hausenloy D, Andreadou I, Antonucci S, Boengler K, Davidson SM, Deshwal S, Devaux Y, Di Lisa F, Di Sante M, Efentakis P, Femminò S, García-Dorado D, Giricz Z, Ibanez B, lliodromitis E, Kaludercic N, Kleinbongard $P$, Neuhäuser M, Ovize M, Pagliaro P, Rahbek-Schmidt M, Ruiz-Meana M, Schlüter KD, Schulz R, Skyschally A, Wilder C, Yellon DM, Ferdinandy P, Heusch G. Practical guidelines for rigor and reproducibility in preclinical and clinical studies on cardioprotection. Basic Res Cardiol. 2018 Aug 17;113(5):39. doi:10.1007/s00395-018-0696-8.

Back and forth from basic science to clinical translation.

Pagliaro P.

Minerva Anestesiol. 2020 Aug;86(8):890-891. doi: 10.23736/S0375-9393.20.14555-3. Epub 2020 Mar 11.

PMID: 32162900 